\title{
ABOUT THE RITUAL OF NAMING THE CHILD
}

\author{
Utkir Islamov, Jurabek Tujchiev
}

\section{international.uzdsmi@gmail.com}

The Uzbekistan State Institute of Arts and Culture, Uzbekistan

\begin{abstract}
The given article researches the ritual of naming children among the peoples of the East, in particular the Uzbek people. It mainly draws attention to the causes and factors of giving names denoting the process of survival and development of the baby.

Keywords: Folklore; Rites; Traditions; Customs; Name; Ethnography; Baby
\end{abstract}

\section{ОБ ОБРЯААХ ИМЕНОВАНИЯ РЕБЕНКА}

\author{
Уткур Исламов, Ажурабек Туйчиев
}

ГосуАарственный институт искусств и культуры Узбекистана

Резюме: В Аанной статье речь ведется об обрялах именовать Аетей у народов востока, в частности узбекского народа. В ней в основном обращается внимание на причины и фракторы дачи имен, обозначающих процесс выживания и развития младенца.

КАючовие слова: фоолькАор, обряды, траАиции, обычаи, имя, нарековедение, млаленец

У кажАого человека есть имя. АюАи привыкли обращаться по нареканию. Если спросят про родителей мы называем имя отца и матери. На улице или в общественных местах ^юли знакомятся, называя свое имя. Поэтому в старину существовали обычаи и обряды Аавать имя м^аленцу, в таких обрядах были своеобразны причитания, разные фантастические верования составили основу имён человека. И все это впослеАствии обогатили ффольклор. В Аействительности, начало науки о фрольклоре связано с солержанием тех ритуалов, которые совершаются после рождения ребенка. Авторы Аанной статьи решили поделиться своими сужАениями О причинах и фракторах, связанных с возникновением обычаев и обрялов нарекать имя ребёнку. 
У кажАого имени есть своя суть и связано с определенным событием или убежлением. Становится критерием семейной Ауховности и культуры нахожАение и изъяснение нужных сведений о своем имени и об имени окружающих детям в семье. Потому что ребенок правильно произносит того имени, суть которого гАубоко понимает. В Аревние времена человек стремился осознать различные секреты природы, бесконечного материального и нематериального мира, уАивлялся стихийно происхолящим событиям, явлениям природы, во многих случаях ^юАи просто боялись nX.

Аревние АюАи стремились найти пути избавления от таких страшных явлений, и чтобы эти явления им не приносиАи вреА они стремились налалить с ними хорошие отношения, возвеличивали и восхваля^и их. И Аумали, что С помощью таких отношений они становятся Аобрыми и не приносят Аюдям вреА. Этих верований в науке называют тотемизмом, анимизмом, фетишизмом, и они исследуются в таких науках, как история, фрилософрия, фрольклор, этнографрия, мифрология, культуроведение и языкознание.

В Аанной статье авторы решили рассмотреть верование анимизма и кратко рассулить о сохранении этого Аревнего представления в современном узбекском антропониме.

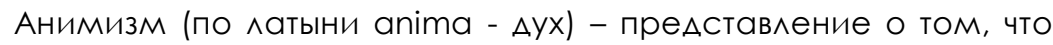
^юАьми, животными, предметами и явлениями управляет дух.

Как отмечается в научных митературах термин анимизм впервые употребля^ немецкий ученый Шталь (1708). Затем этот термин И. Тейлор начал употреблять в области этноградрии (1871).

В учении об анимизме говорится о том, что со всеми вещами в мире управляет Аух, он может перехолить из одного преАмета или явления в Аругое и может привоАит положительному или отрицательному исходу. На основе этой точки зрения Аревний человек Аумал, что когла человек умирает его Аух переходит м^аАенцу. 


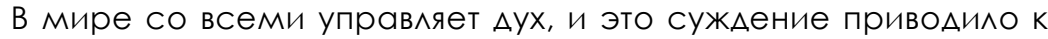
такому выводу, что являются одушевленными все существующие

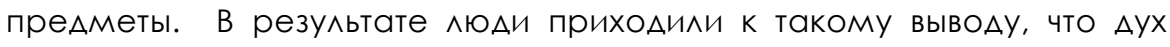
перехолит от одного человека и предмета в Аругое. Поэтому у народов всего мира, в том числе у узбекского народа есть такое поверие, согласно которого не нарекать м^аленца именем живого или умершего человека с отрицательными качествами.

У узбекского нарола есть Аобрая тралиция Аать млаленцу имена великих преАков, которые стали горАостью нации, если м^аленец часто болеет, капризничает, Аумали что это имя «Аавит своим весом». 3Аесь, может быть, умершему не понравилось то, что его именем назвали ребенка.

ОтсюАа виАно, что есть какая-то невиАимая связь межАу предметом и его наименованием. Поэтому считали, что знание наименование предмета поможет знать суть, истинное содержание этого же предмета. По причине этого, Аревние $ю$ юи $\Delta \wedge я$ того, чтобы раскрыть суть предмета стремились прежле всего определить, познать содержание предмета. Аревнегреческие ученые также считали, что имеется какая-то связь между предметом и его наименованием, познание солержание человека или предмета приводит к раскрытию сути того человека или предмета. В науке много говорилось о преАставлении Аревних ^юАей, касающиеся отношению межлу предметом и его наименованием. Это очень сложная, многогранная проблема. Авторы Аанной статьи вкратце излагают свое мнение, по поводу анимистических представлений в узбекской антропонимике.

Известно, что в некоторых семьях несколько новорожленные не выживают, и поэтому основной целью родителей становится какими-то путями сохранить своего м^аленца, огородить ребенка от различных опасностей, чтобы он вырос зАоровым, жил Аолго как его окружающие. Как высше отмечено, у Аюдей было поверие о том, что у всякого предмета есть Аух, Ауша, поэтому они стремились Аать м^аленцу имя такого предмета, который является прочным, 
Аолговечным, выносливым И стойким. АюАИ считали, что все эти качества дух прочности предмета перехолит м^аленцу, которого назвали наименованием этого прелмета. То обстоятельство показывает отражение анимистических взгляАов в антропонимистических убежлениях.

В узбекском языке есть такие имена, основу которых составили наименование тверлых, прочных, острых, стойких предметов. При наименовании ребенка наименованиями таких предметов АюАи вверять в то, что естественно-оризические характеристики и качества этих предметов перехолит в ребенка и он булет расти терпеливым различным невзголам, и самое главное, Аух этих предметов охраняет ребенка. Эти преАметы следующие:

1. Естественно твердые предметы, которые встречаются в природе: камень - Тош, Тошбой, Санбай, Санги, Сангтош, Сангчин, Санзор;

2. Естественные, но переработанные человеком минарелы: Пўлатбой (сталь), Чуён (чугун), Метин (твердый), Темир (железо), Темирпулат (железо-сталь), Изора (свинец).

3. Обихолные вещи, созданные человеком в процессе полготовки бытовых преАметов: Балтабай (топор), Болғабой (молоток), Тешабой (мотига), Чўтбой, Кетмонбой, Кетменой, Чукмор (кирка), Чукморкул, Чукморбой, Тукмак (молот), Чукши, Тунг (сосуА из меАи), Занжир (цепь), Занжира, Зулорин (тверлая цепочка), Зулфрина, Сувон (напильник);

4. Военные снаряжения, слеланные из крепких метал^ов: Килич (сабля), Киличбой, Киличмурол, Ханжар (кинжал), Ханжара, Шамшир (меч), Микроз (олово), Совут (кольчуга);

5. Многолетнее дерево тверлой породы: Арча (можевельник), О^мурт (груша), СаАи (вяз), Гужум (вяз), Чилон, Чилонжийла (унаба), Карагай (пихта), Чинар (п^атан), Чинора, Ёвшон (полынь), Бурчок (горошина), Нухот (горох) и мругие.

В узбекском языке есть такие имена, которые образованы из Авух слов путем сращения слов, обозначающих твердых предметов: 
Тоштемир (камень, железо), Тошпулат (камень, сталь), Болтатош (топор, камень), Темиртош (железо, камень), Чутпулат (мотига, сталь) и Аругие.

Возникновение имен связано не только Ауховной стороной жизни, но и охватывает рял материальных, практических мероприятий. Эти мероприятия осуществляются тогАа, когАа $А$ ают имя м^аленцу. Ученый Э. Бегматов в своей книге «Узбекские имена» пишет о следующем интересном обряле, который $А$ сих пор сохраняется срели узбекского нарола: «У узбеков есть имена Сотиболди (продал-покупал), Соттибой (продал), Сотимбека (жен), Соткиной (жен), Сотилган и Аругие. Появление этих имен связано с осуществлением обряла «покупки» м^аленца. В прошлом в некоторых семьях Аети не выживали, поэтому родители очень налеялись на обрял «пролал-покупал». согласно этому обряду после рожления ребенка его положили на олну чащу весов, а на другую различные продукты питания (в богатых семьях в замен продукт питания положили Арагоценные вещи). Управляли чаши весов. В это время межАу повитухой и хозяином Аома состоится Аиалог, Связанный этим обряАом покупки и проАажи, после Аиалога ма^ютку считали «проданным». Продукты взяла повитуха, ей Аополнительно

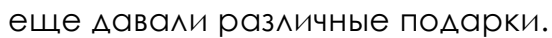

Родители, Аавая имена своим детям названия твердых вещей твердо верили в то, что их детей в $А$ иьнейшем будут защищать качества $(\Delta y x)$ этих твердых предметов. Эти имена являются результатом анимистического убежления Аревних АюАей и считаются

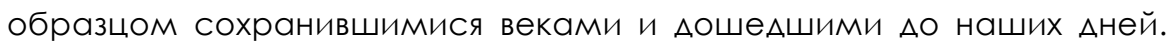
Подобные имена дают возможность проследить процесс ощущения Аревними АюАьми секреты окружающего мира и постепенного роста комплекса знаний о Аухе, жизни, преАметов. САовом, они составили сути мировоззрения, знания, простой культуры и Ауховности Аревнего человека. Вышеуказанные можно считать Аингвистико-Ауховным наслеАием философрско-религиозной веры наших предков. Полобные тралиции и обрялы, приналлежащие вере 
и прав фоолькАористики.

Словом имя становится постоянным спутником человека и считается важным Ауховным наследием, когАа-то приналлежавшим родителям и прародителям, и всегАа мы Аолжны помнить, что это имя как наслеАИе АО^Жно остаться ценностью А^я наших потомков, И чтобы они всегАа горАились своим именем, придающим такие чувства как героизм, терпение, гуманизм, патриотизм.

\section{ヘитература / References}


КУАТУРНО-ИСТОРИЧЕСКО НАСАЕАСТВО:

ОПАЗВАНЕ, ПРЕАСТАВЯНЕ, АИГИТААИЗАЦИЯ

CULTURAL AND

HISTORICAL

HERITAGE

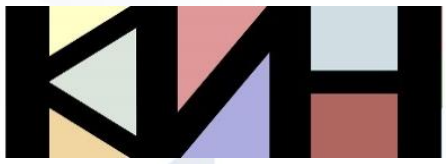

PRESERVATION PRESENTATION DIGITIZATION
Материалите в сборника са обект на авторско право. Разрешава се безвъзмезАното ползване на техни електронни/ хартиени копия само за лична употреба или обучение, при пь^но цитиране на текущата страница и слеА писмена декларация от цитиращия за Аипса на търговски намерения. За копиране под Аруга фрорма, препубликуване или публикуване на сървъри се изисква писмено разрешение и/или заплащане.

(С) Авторски колектив, 2019 Технически реАактори: Николай Ноев Калина Сотирова-Вълкова Ка^оян Николов

\section{Editors}

Galina Bogdanova Vanya Mateeva

This work is subject to copyright. Open and free of charge use of digital/hard copies of publications is granted only for personal or educational use, with full citation of the current page, and after written declaration of the quoting side for not-commercial Intention. For any other reproducing types, republishing, photocopying, recording, or any other storage retrieval system/ server written permission and/or fee is required.

(C) Authors` Group, 2019

Technical editors:

Nikolay Noev

Kalina Sotirova-Valkova

Kaloyan Nikolov

\section{Научна пореАица: том 5, брой 2 (7)/2019 Science series: vol. 5 , issue $2(7) / 2019$}

www.math.bas.bg/vt/kin

ISSN: 2367-8038 